\title{
THE ROLE OF LEADERSHIP IN NATURAL RESOURCE CONSERVATION AND SUSTAINABLE DEVELOPMENT - A CASE STUDY OF LOCAL SELF-GOVERNMENT OF EASTERN SERBIA
}

\author{
Nebojša Marjanović ${ }^{1}$, Violeta Jovanović ${ }^{2}$, Tatjana Ratknić3 ${ }^{3}$ Džejn Paunkovićc \\ *Corresponding author E-mail: violeta.jovanovic@fmz.edu.rs
}

A R T I C L E I N F O
Review Article
Received: 06 September 2019
Accepted: 18 September 2019
doi:10.5937/ekoPolj1903889M
UDC
502.131.1:001.87:352(497.11-11)

Keywords:

Leadership, Local selfgovernment, Natural resources, Sustainable development.

JEL : Q010

\begin{abstract}
A B S T R A C T
Local authorities have a very important role in preserving natural resources and achieving the concept of sustainable development. Leadership, but primarily sustainable leadership, plays a major role in the management of natural resources. Sustainability at local level refers not only to environmental issues such as the conservation of natural resources, energy and environment but also efforts to involve the community in the processes, develop organizational capacities and promote the principles of sustainable development. This research analyses the importance and role of the leadership of local self-government in the preservation of natural resources and the realization of the concept of sustainable development. The research was performed in local governments on the territory of Eastern Serbia. The correlation method is used to determine the interrelation between leadership and sustainable management of natural resources and practical application of the basic principles of sustainable development.
\end{abstract}

(C) 2019 EA. All rights reserved.

\section{Introduction}

Local self-government with all its institutions, organizations and individuals must make a serious effort to recognize, register and qualitatively and quantitatively explore natural resources and recognize their key role in launching a new cycle of municipal

1 Nebojša Marjanović, Municipality of Boljevac, Serbia, Kralja Aleksandra 24, 19370 Boljevac, Serbia, +38163402611, kzmboljevac@gmail.com, https://orcid.org/0000-00023958-9460

2 Violeta Jovanović, Assistant professor, Faculty of Management Zajecar, Park šuma Kraljevica bb, 19000 Zaječar, Serbia, +381 63 8879925, violeta.jovanovic@fmz.edu.rs, https://orcid.org/0000-0003-3624-4341

3 Tatjana Ratknić, Institute of forestry, Kneza Viseslava 3, 11030 Beograde Serbia, +381 65 5203548, tatjanaratknic@yahoo.com,https://orcid.org/0000-0002-6333-7079

4 Džejn Paunković, Full professor, Faculty of Management Zajecar, Park šuma Kraljevica bb, 19000 Zaječar, Serbia, +381 19430 800, jane.paunkovic@fmz.edu.rs, https://orcid. org/0000-0002-4580-7612 
development. Sustainable exploitation of natural resources within municipalities which gives rise to sustainable future of their citizens is based on the strategies of sustainable development of the local community as part of the general strategic planning of the municipal development.

Sustainability implies that people use natural resources to the extent that will allow them to regenerate naturally. Sustainable development is a tendency to make the world a better place, balancing social, economic and environmental factors. It is a harmonious relationship between ecology and economy, which aims to preserve the world's natural resources for future generations. Some authors state that sustainability indicators are based on the attempt to measure or determine the progress of the economic development in two directions: sustaining human wellbeing or preserving the capacity to provide wellbeing (Petrov et al., 2018).

In Serbia, the principles of good governance in municipalities, which include effective and efficient use of natural resources, do not support sustainable progress. One of the greatest challenges in this process is the lack of professional and organizational knowledge and internationally-recognized campaigns for the sustainable development of cities and municipalities. Another challenge is sustainable leadership which is essential for the application of the principles of sustainable development, efficient management, and conservation of natural resources (Paunković et al., 2018). The paper uses the regression analysis to confirm the effects of the leadership of local selfgovernment in Eastern Serbia on the management of natural resources and sustainable development of this region.

\section{Sustainable leadership}

In modern business conditions characterized by major dynamic changes, organizations and society as a whole need good leaders. Leaders have the greatest impact on organizational performance. The success of an organization depends on their skills and abilities. There have been many theories on leadership, and consequently a large number of definitions of this term. Stoner et al., defined leadership as "the process of influencing and directing all organizational members involved" (Stoner et al., 1995). According to Grünberg, leadership is "a process in which some members of a group influence others toward group or organizational goals"(Grünberg, 2001). Robins defines leadership as "the ability to influence the group to achieve organizational goals" (Robbins, 2003). Later on, in his view of leadership Robins adds the element of vision so that leadership becomes "the ability to influence the group to achieve the vision or goals of the organization" (Robbins, Judge, 2013, p.368).

Leadership can be defined as a process in which "we make people go where they wouldn't have gone on their own" (Visser, 2011). According to Peters, leadership is about "discovering the passion, persistence, and imagination to get results, being able to find the Wow factor and think the weird thoughts necessary to learn and thrive in a disruptive age“" (Peters, 1989). 
There is something all these definitions have in common - the essence of leadership is reflected in the use of the influence of leaders on their followers-employees in achieving organizational goals. There is another question to answer: What does sustainable leadership mean? One definition of a sustainable leader may be: "A sustainable leader is someone who inspires and supports action towards a better world."

The Sustainability Leadership Institute (2011) offers another definition, suggesting that sustainability leaders are "individuals who are compelled to make a difference by deepening their awareness of themselves with the world around them. In doing so, they adopt new ways of seeing, thinking and interacting that result in innovative, sustainable solutions." (Sustainability Leadership Institute, 2011).

A review of literature on leadership reveals that there is no particular school of sustainability leadership, or more precisely leadership for sustainability. It is rather a practical blend of leadership qualities that apply to a particular context. To survive, organizations will have to accept the concept of sustainable leadership. Bearing in mind the theory of leadership and the practical aspect of sustainability, Visser proposed a model of sustainable leadership which has the following 3 components:

- the external and internal context of leadership,

- $\quad$ traits, styles, skills, and knowledge of individual leaders and

- leadership actions (Visser, 2011).

None of these elements is unique to leaders, but collectively they reflect a distinctive set of traits and actions in response to sustainability.

In practice, sustainable leadership is aimed at introducing major changes, either into the political and economic system, into the practical and business performance of an organization, or at a wider social level. Thus, the model of sustainable leadership is exclusively about the introduction of change.

In the model of sustainable leadership, the context refers to the conditions or environment in which the leader performs/ works and which have a direct or indirect influence on institutions and decision-making. The environment can be either external or internal. When considering the external environment, ecological, economic, political, cultural, and community contexts are taken into account, while the internal environment includes factors such as organizational culture, governance structure, and organizational reach. When developing a sustainable business strategy, leaders must take into account the impact of the organization and its business on the environment, comply with laws and must fit into the cultural context of the society. The role of leaders is to build the organizational culture and structure that allows for sustainable business. This is a culture that fosters interpersonal relationships, mutual respect, and teamwork, and this is a structure that enables employees to participate in making decisions important for the organization's business. 


\section{The qualities of sustainability lesdership}

Sustainability leadership implies that leaders must be capable of making business sustainable for which they must possess their own styles, skills, and knowledge. The combination of all these features makes a leader unique. These leaders must possess long-term integrity and care for their followers, but they must also set certain demands for their followers to meet. The fact is that individual leaders do not embody all of these traits, styles, skills, and knowledge into their own leadership model, but accept those that suit their personality and circumstances so as to achieve the highest efficiency and implement the concept of sustainability in business (Center for Excellence and Leadership et al, 2007).

Sustainability leaders must care for the well-being of humanity and be guided by ethical values. Sustainable leadership is often associated with care for people's well-being and all other forms of life, as well as ethical standards. Tuppen and Porritt look on the ethics in sustainable development as the basis of today's equation, ecological justice, intergenerational equity, and stewardship (Tuppen and Porritt, 2003).

Sustainability leaders should be people who explore - open-minded leaders. They must actively search for new knowledge and diverse opinions. This means that they must be willing to question the value of products or services to society and be ready to challenge the traditional models of economic growth.

Sustainable leadership implies that these leaders must be visionary and courageous people. According to Collins, the leader must have the absolute faith that he can and will prevail in the end, regardless of the difficulties, and at the same time confront the most brutal facts of their current reality, whatever they might be (Collins, 2001). Leaders must be good at sharing the vision with others, enabling a dialogue that inspires action and leads to common opinions (active listening, emotional intelligence, reflection) and creating conditions that encourage learning from experience.

Sustainable leaders concentrate on creating a culture and structure that provides support and encouragement to collaborators and recognizes success and achievements. Sustainability leaders "build a climate of support and responsibility, not a climate of control" (Center for Excellence and Leadership, 2007). Similarly, Immelt says: "It's critical to understand people, to always be fair, and to want the best in them"(Immelt, 2007).

Sustainability leaders must be innovative and ready to respond to various challenges. This means they are good at predicting possible solutions or alternatives, thinking beyond standard decision frameworks by introducing creativity into thinking and practice.

Sustainability leaders see the importance of interdisciplinarity. They assimilate the knowledge of physical sciences, social sciences, technology, business, and other disciplines. Sustainability leaders must be aware of the impact their organization has on the environment, society, and all stakeholders. They must constantly search for opportunities to create new markets and develop the organization as a whole. It is also important to ensure the transparency of the organization. The impact of the organization 
on the environment can be presented in several ways. One way is the environmental accounting method that is used to understand the impact of sustainable development on the organization's profit. Environmental accounting shows how much it would cost to avoid the environmental impact of its energy use, waste disposal, and water treatment.

Sustainability leaders must be aware of the importance of respecting diverse opinions of stakeholders. They are open to different points of view and different belief systems, both within the community and at a wider, global level or in the cultural and political fields, and they must be able to adequately incorporate all these different views. Immelt states that "even if the leaders have the answer, they will often let the team find its own way" (Immelt, 2007).

Sustainability leaders give equal importance to the governance system and corporate culture. The governance system is important because it represents a set of decisions that leaders or general managers make and which must be implemented to achieve organizational goals. However, they know that ultimate responsibility lies at the highest level. Therefore, leaders must shape such a corporate culture that will generate the necessary motivation in employees to conduct their activities and make the best possible decisions (Shafique \& Kalyar, 2018).

\section{Sustainabile lesdership in the context of local self - government}

Sustainability in a local context implies not only environmental issues such as conservation of natural resources, energy, and environment but also efforts to involve communities in the processes, develop organizational capacities, and promote the principles of sustainable development. Sustainable leadership is the promotion of a wide range of practices by a large number of actors including Council members, citizens, legislators, and others. In his "Dynamics of Leadership", Van Wart defines the sustainable leadership of local governments as "a kind of social change leadership"(Van Wart, 2011). However, the key role of state administration and local authorities (in local sustainability) has been largely ignored in the literature.

The role of local self-government is critical because of its close relatedness to environmental issues (Jepson, 2004, Saha \& Paterson, 2008). As many local governments have turned to the implementation of sustainable development, it has become particularly important how to improve the implementation (Krause, 2010; Sharp, Daley \& Lynch, 2011; Wang, Hawkins, Lebredo \& Berman, 2012). In this regard, leadership is one of the most important factors in implementation (Aristigueta \& Zarook, 2011; De Waal, 2010; Kaiser, Hogan \& Craig, 2008; Pressman \& Wildavsky, 1973; Trottier, Van Wart \& Wang, 2008).

While local leaders, citizen/activist groups and governments (state legislatures) are undoubtedly important in initiating and enhancing sustainability, executive authorities have the most important role in local sustainability becoming increasingly vigorous in its implementation. Executive authorities ensure decision implementation, which can be quite complex and time-consuming; they play an important role in overcoming 
organizational resistance to change; they work with the local community to improve educational and regulatory elements with the aim of increasing effectiveness (Borins, 2000). Wang and his associates examined the most acceptable type of leadership theory (Wang et al, 2014). This process started with the establishment of a framework that defines sustainable leadership at the local government level of the US and the definition of the most appropriate general theories of leadership. Based on the results of their research, Wang and associates provided a comprehensive definition of sustainable leadership at local government level. According to them, sustainable leadership can be defined as the process of promoting specific environmental, economic, and social issues by a wide array of actors that include local council members, citizens, state legislators, and public administrators that together produce positive outcomes in communities (Wang et al, 2014; Zhao, J. et al, 2018).

In general, when it comes to the theory of sustainable leadership and the practice to be carried out at the local level, there are several conclusions:

- local authorities play an important role in the implementation of sustainability at the local level,

- $\quad$ it is important to raise the awareness of the local administration,

- leaders of local governments must take appropriate managerial actions.

Managers of local governments must be both good leaders and good managers. A broad array of different approaches used by leaders in different local governments and city administrations indicate that there is no single path towards achieving sustainable development. The relatively low level achieved in the implementation of the concept of sustainable development in the local governments of Eastern Serbia stems from a complex and challenging environment, a lack of financial resources, insufficient knowledge on sustainable development, a low level of motivation of employees in local self-government and many other factors. This suggests that a strong managerial and leadership capacity of local government leaders is needed to implement specific sustainability initiatives.

\section{Eastern Serbia region - location and natural resources}

Eastern Serbia is located between the Danube River and two corridors: Corridor X (Serbia) and Corridor IV (Bulgaria). It borders Romania in the north and Bulgaria in the east. It covers an area of $7,133 \mathrm{~km}^{2}$ and includes two administrative districts the administrative district of Bor and the administrative district of Zaječar, with the municipalities of Knjaževac, Boljevac, Sokobanja, Negotin, Kladovo, and Majdanpek.

The territory of Eastern Serbia is predominantly hilly-mountainous, with arable land accounting for about $45 \%$ of the entire territory. The most developed agricultural systems are livestock farming, crop farming, fruit and vine growing. Forests occupy about 40\% of the total area of Eastern Serbia. In terms of its geographical position, the area of Eastern Serbia belongs to the continental climate zone with pronounced temperature 
extremes, large precipitation deviations and unfavorable distribution of rainfall during the year. The main industries of Eastern Serbia today are power generation, copper production, agriculture, forestry, wood processing industry. They are accompanied by the clothing and footwear industry, chemical industry, tourism, construction, etc. (http://www.rasr.si/en/files/default/Isto\%C4\%8Dna\%20Srbija.pdf

The resources that can foster the development of Eastern Serbia are spas and thermomineral springs (Sokobanja, Brestovačka Banja, Gamzigradska Banja), copper mines (Bor and Majdanpek), anthracite mines, coal mines, protected natural areas ("Djerdap" National Park, Stara Planina Nature Park...), cultural heritage (Felix Romuliana (UNSECO), Golubac fortress, Sokograd).

Eastern Serbia is a rural region and one of the least developed regions in Serbia with the high unemployment rate, poor infrastructure, population ageing, and outflow of young adults. The population decline in rural areas is twice as high as in urban areas, and it is most pronounced in the Southern and Eastern Serbia Regions (http://www.stat.gov.rs/ sr-latn/oblasti/stanstvo/). The educational structure of the population is characterized by disturbing trends, especially compared to the urban population. It is most unfavorable in the South-Eastern and Eastern Serbia Regions where as many as 58\% of the population don't have more than primary education, and half of them don't have primary school completed (http://www.stat.gov.rs/sr-latn/oblasti/stanovnistvo/). Rural areas are confronted with numerous problems. Hence there is an array of determinants that affect successful management of rural development (Đukić et al., 2017, Vilke et al., 2019). In order to encourage young people to live and work in rural areas, it is necessary to increase the investment attractiveness of these regions. This is where local authorities should occupy a crucial role. Leaders and employees in local governments must be aware of the importance of sustainable development and incorporate the principles of sustainability into the management process.

\section{Methodology}

The research was carried out in local governments on the territory of Eastern Serbia. (Boljevac, Bor, Knjaževac, Zaječar, and Kladovo) during September 2018. The survey method was used as the research method. The respondents were local self-government employees. Their responses, attitudes, and opinions were used to determine the type and performance of leadership in local governments, and to determine the role of leaders in natural resource conservation and implementation of the sustainable development concept at the local level. Specially designed forms (questionnaires) were used to obtain the necessary data and information. This research was conducted using structured questionnaires (surveys). Respondents were asked to answer the questions by selecting the most appropriate answer option. Questionnaires for leadership testing were adapted to the questionnaire used by Jovanović (Jovanović, 2016) and Stevanović (Stevanović, 2017 ) in their research. Statistical processing of the obtained data was performed using the SPSS software package (Statistical Package for the Social Sciences). The starting hypothesis of the study is: "Effective local self-government leadership is correlated with the principles of sustainable development." 
In order to determine the interdependence between leadership as the independent variable and sustainable management of natural resources and practical application of the basic principles of sustainable development as dependent variables, method of correlation is used. Correlation is a bivariate analysis that measures the strength of association between two variables and the direction of the relationship. It's a statistical technique which determines how one variables moves/changes in relation with the other variable. The main result of a correlation is called the correlation coefficient ("r"). It ranges from -1.0 to +1.0 . A value of \pm 1 indicates a perfect degree of association between the two variables. As the correlation coefficient value goes towards 0 , the relationship between the two variables will be weaker. The direction of the relationship is indicated by the sign of the coefficient; a + sign indicates a positive relationship and $\mathrm{a}-$ sign indicates a negative relationship. A correlation can be calculated between two numerical values or between two category values. Pearson $r$ correlation is the most widely used correlation statistic to measure the degree of the relationship between linearly related variables.

\section{Research results and discussion}

The data obtained were used to examine the role of local self-government leadership in the management of natural resources and implementation of the concept of sustainable development and to determine how responsibly local self-government leaders act towards their employees. Base on the obtained data, we determined:

- $\quad$ how much the employees in local governments are familiar with the concept of sustainable development and how much they are willing to expand their knowledge in this field;

- how leaders motivate employees, how they involve them in the decisionmaking process and whether they care about their needs (an important aspect of the sustainable business) and

- how important the role of leadership is in achieving the concept of sustainable development.

Table 1. Responses to a group of questions about leadership

\begin{tabular}{|c|c|c|c|c|c|}
\hline Leadership & Boljevac & Bor & Kladovo & Knjaževac & Zaječar \\
\cline { 2 - 6 } & Average & Average & Average & Average & Average \\
\hline $\begin{array}{c}\text { Managers make decisions taking into } \\
\text { account the needs of employees }\end{array}$ & 3.44 & 3.09 & 3.24 & 3.24 & 2.90 \\
\hline $\begin{array}{c}\text { Local self-government employees } \\
\text { publicly review decisions of their } \\
\text { immediate superiors when they } \\
\text { disagree with them }\end{array}$ & 2.86 & 3.09 & 3.03 & 3.12 & 2.80 \\
\hline
\end{tabular}


Economics of Agriculture, Year 66, No. 3, 2019, (pp. 889-903), Belgrade

\begin{tabular}{|c|c|c|c|c|c|}
\hline \multirow{2}{*}{ Leadership } & Boljevac & Bor & Kladovo & Knjaževac & Zaječar \\
\hline & Average & Average & Average & Average & Average \\
\hline $\begin{array}{l}\text { Employees in the local self- } \\
\text { government publicly review } \\
\text { decisions of the general manager } \\
\text { when they disagree with them }\end{array}$ & 2.50 & 2.89 & 2.66 & 3.06 & 2.53 \\
\hline $\begin{array}{l}\text { There is a good working atmosphere } \\
\text { in the local self-government }\end{array}$ & 3.94 & 3.77 & 3.37 & 3.41 & 3.23 \\
\hline $\begin{array}{c}\text { Management encourages employees } \\
\text { to acknowledge the mistakes from } \\
\text { which they can learn }\end{array}$ & 3.69 & 3.20 & 3.21 & 3.44 & 3.43 \\
\hline Co-workers respect each other & 4.28 & 4.00 & 3.97 & 3.71 & 3.60 \\
\hline $\begin{array}{l}\text { Superiors care about the needs of } \\
\text { local self-government employees }\end{array}$ & 3.56 & 3.14 & 3.05 & 3.12 & 3.03 \\
\hline $\begin{array}{l}\text { Managers often stress their position } \\
\text { in the local self-government }\end{array}$ & 3.36 & 3.43 & 3.50 & 3.12 & 3.47 \\
\hline $\begin{array}{l}\text { Managers are primarily interested in } \\
\text { fulfilling their tasks }\end{array}$ & 4.08 & 3.83 & 3.45 & 3.82 & 4.17 \\
\hline $\begin{array}{c}\text { Managers initiate changes in the } \\
\text { local self-government }\end{array}$ & 4.00 & 3.54 & 3.50 & 3.82 & 3.40 \\
\hline $\begin{array}{l}\text { Managers spend most of their } \\
\text { working time exercising strict } \\
\text { supervision of their employees in the } \\
\text { local self-government }\end{array}$ & 2.78 & 2.71 & 3.39 & 3.09 & 2.70 \\
\hline $\begin{array}{l}\text { Managers find it important to } \\
\text { generate motivation and satisfaction } \\
\text { of employees in the local self- } \\
\text { government }\end{array}$ & 3.03 & 2.74 & 2.71 & 3.15 & 2.70 \\
\hline $\begin{array}{l}\text { Employees in the local self- } \\
\text { government are motivated and } \\
\text { satisfied }\end{array}$ & 2.81 & 2.34 & 2.16 & 2.71 & 2.57 \\
\hline $\begin{array}{l}\text { The employee commitment to } \\
\text { the organization is important to } \\
\text { managers }\end{array}$ & 4.08 & 3.57 & 3.24 & 3.59 & 3.87 \\
\hline
\end{tabular}

Source: Author's Calculation 
Table 2. Responses to a group of questions related to sustainable development

\begin{tabular}{|c|c|c|c|c|c|}
\hline \multirow{2}{*}{ Sustainable development } & Boljevac & Bor & Kladovo & Knjaževac & Zaječar \\
\hline & Average & Average & Average & Average & Average \\
\hline $\begin{array}{c}\text { I am familiar with the concept of } \\
\text { sustainable development }\end{array}$ & 4.22 & 3.14 & 3.18 & 3.53 & 3.60 \\
\hline $\begin{array}{c}\text { I am interested in learning and } \\
\text { expanding knowledge about } \\
\text { sustainable development }\end{array}$ & 4.17 & 4.00 & 3.95 & 3.91 & 4.17 \\
\hline $\begin{array}{l}\text { Concepts of sustainable development } \\
\text { and environmental protection have the } \\
\text { same meaning }\end{array}$ & 3.17 & 3.43 & 2.89 & 3.26 & 2.87 \\
\hline $\begin{array}{c}\text { Sustainable development enables the } \\
\text { development of industry, regardless of } \\
\text { natural resources }\end{array}$ & 3.36 & 3.17 & 2.84 & 2.94 & 2.90 \\
\hline $\begin{array}{l}\text { Preservation of natural resources is } \\
\text { important for sustainable development }\end{array}$ & 4.69 & 4.46 & 3.97 & 4.35 & 4.47 \\
\hline $\begin{array}{c}\text { Increasing energy efficiency plays a } \\
\text { key role in achieving the concept of } \\
\text { sustainable development }\end{array}$ & 4.56 & 4.09 & 4.11 & 4.21 & 4.37 \\
\hline $\begin{array}{c}\text { Achieving sustainable development } \\
\text { is not possible without reducing the } \\
\text { consumption of energy and natural } \\
\text { resources }\end{array}$ & 4.17 & 3.83 & 3.97 & 3.62 & 4.10 \\
\hline $\begin{array}{l}\text { My local self-government carries out } \\
\text { various activities that contribute to the } \\
\text { preservation of natural resources }\end{array}$ & 3.83 & 3.46 & 2.92 & 3.76 & 3.27 \\
\hline $\begin{array}{l}\text { My local self-government carries out } \\
\text { various activities that contribute to the } \\
\text { protection of the environment }\end{array}$ & 4.06 & 3.37 & 3.11 & 3.82 & 3.33 \\
\hline $\begin{array}{c}\text { My local self-government implements } \\
\text { various projects that increase energy } \\
\text { efficiency }\end{array}$ & 4.08 & 3.26 & 3.18 & 3.82 & 3.03 \\
\hline $\begin{array}{l}\text { Local self-government is the initiator } \\
\text { of a large number of sustainable } \\
\text { development projects }\end{array}$ & 3.97 & 3.37 & 2.97 & 3.59 & 3.00 \\
\hline $\begin{array}{l}\text { Local self-government employees are } \\
\text { constantly receiving information on } \\
\text { sustainable development projects }\end{array}$ & 3.36 & 3.20 & 2.39 & 3.12 & 2.37 \\
\hline $\begin{array}{l}\text { It is important to involve citizens in } \\
\text { sustainable development (SD)projects }\end{array}$ & 4.53 & 4.17 & 3.92 & 4.29 & 4.40 \\
\hline $\begin{array}{l}\text { Local authorities (LA) are always } \\
\text { committed to involving citizens in } \\
\text { designing SD projects }\end{array}$ & 3.47 & 2.86 & 2.71 & 3.53 & 2.93 \\
\hline $\begin{array}{c}\text { LA play a key role in achieving } \\
\text { sustainable development at the local } \\
\text { level }\end{array}$ & 4.39 & 3.66 & 3.55 & 4.26 & 4.10 \\
\hline $\begin{array}{c}\text { When formulating policies, LA } \\
\text { must take into account economic, } \\
\text { environmental and social development } \\
\text { goals }\end{array}$ & 4.53 & 4.06 & 4.11 & 4.26 & 4.30 \\
\hline
\end{tabular}


The tables 1. and 2. present the average values of the answers given by the employees in the local governments of Eastern Serbia.

Looking at the link between leadership and the concept of sustainable development, it is assumed that there is a correlation between these two phenomena. Organizational leadership must be oriented towards the principles of sustainable development. Effective management of natural resources implies that leaders in local governments are well aware of the principles of sustainable development which they apply in practice.

This means that efficient management of natural resources and sustainable development result from efficient local self-government leadership. Thus, the application of the concept of sustainable development is a dependent variable, and leadership is an independent variable. The dependence between the variations in the application of the concept of sustainable development and leadership in local governments will be explained using the correlation method. The coefficient of determination and correlation are shown in the following tables.

Table 3. - Coefficient of determination and correlation

\begin{tabular}{|c|c|c|c|c|}
\hline $\begin{array}{c}\text { Regression } \\
\text { parameters }\end{array}$ & $\mathbf{r}$ & $\begin{array}{c}\text { Coefficient of } \\
\text { determination }\end{array}$ & $\begin{array}{c}\text { Corrected coefficient of } \\
\text { determination }\end{array}$ & Standard error \\
\hline & 0.592 & 0.351 & 0.347 & 0.4941 \\
\hline
\end{tabular}

Source: Author's Calculation

The value of the coefficient of correlation $(\mathrm{R})$ is 0.592 and it is positive. Thus, it can be concluded that there is a direct positive correlation between the observed phenomena (leadership and the concept of sustainable development). The value of $\mathrm{R}$ ranging between 0.50 and 0.75 indicates a moderate to good relationship between the variables. In this case, the value of the coefficient $\mathrm{R}$ is 0.592 , which suggests that there is a moderate to good connection between the leadership and the implementation of the sustainable development concept.

The value of the corrected coefficient of determination is 0.347 . It indicates the existence of dependence between the observed variables. Based on the value of the coefficient of determination, it can be said that in $35 \%$ of cases the leadership of local governments has an impact on the implementation of the concept of sustainable development.

Since the probability of error is small (0.000), the confidence interval is very high (99\%). The value of the F- test is statistically significant. This indicates that the coefficient of determination is very important for the prediction of the variation between the variables.

It is further necessary to analyze the shape and strength of the relationship between the indicators. The statistical model parameters, intercept and slope ( $\beta 0$ and $\beta 1)$ were tested using the T-test. The null hypothesis is that there is no linear relationship between the variation of the observed events in the basic set, i.e. that $\mathrm{X}$ does not affect Y: $\mathrm{H} 0: \beta=0$. A two-way alternative hypothesis $\mathrm{H} 1$ is also set: $\beta \neq 0$. The following table shows the 
statistical parameters for the variables of leadership and awareness of the concept of sustainable development.

Table 4. Statistical parameters for the observed variables (leadership and the concept of sustainable development)

\begin{tabular}{|c|c|c|c|c|c|}
\hline \multirow{2}{*}{$\begin{array}{c}\text { Statistical parameters of } \\
\text { the model }\end{array}$} & \multicolumn{2}{|c|}{$\begin{array}{c}\text { Non-standardized } \\
\text { coefficients }\end{array}$} & \multirow{2}{*}{$\begin{array}{c}\begin{array}{c}\text { Standardized } \\
\text { coefficients }\end{array} \\
\text { Beta } \\
\end{array}$} & \multirow[t]{2}{*}{$t$-test } & \multirow{2}{*}{$\begin{array}{c}\text { Probability } \\
\text { of error }\end{array}$} \\
\hline & $\mathrm{B}$ & Std. error & & & \\
\hline Intercept/constant & 1.928 & 0.185 & & 10.445 & 0.000 \\
\hline Leadership - slope & 0.531 & 0.055 & 0.592 & 9.615 & 0.000 \\
\hline
\end{tabular}

Source: Author's Calculation

The value of $\beta 1$ is different from zero and amounts to 1.928 . If the value of $\beta 1$ is different from zero, the regression line can be used for prediction. The probability value is less than the significance level (0.05), and the value of the t-test for the assessment of the slope is statistically very significant (9.615). Since the p-value is less than the level of significance and the probability of error is less than the adopted one, the null hypothesis is rejected and the alternative $\mathrm{H} 1: \beta \neq 0$ is adopted.

Based on the obtained results it can be concluded that the coefficient of determination shows that in $53 \%$ of cases the leadership of local self-government has an impact on the implementation of sustainable development concepts in local governments. It follows that the starting hypothesis is confirmed: "Effective local self-government leadership is correlated with the principles of sustainable development."

\section{Conclusions}

There is a goal and a tendency that local self-government has to achieve. There are certain conditions and limitations, as well as the opportunity to accept the most suitable type of behavior from a set of possible behaviors. In organizational behavior, it is very important to respect certain principles. These principles relate to the thinking and behavior of people who manage local governments and working processes or participate in them.

The relationship between local self-government and natural resources is defined by national, regional and local strategies as well as legal regulations. However, in addition to legal frameworks, numerous other factors affect the conservation of natural resources and implementation of the concept of sustainable development in local selfgovernment. Our research showed that one of the most decisive factors is the leadership of local self-government. Leadership is an important factor that affects the progress of the local community and enhances the quality of life of people living in that community. Based on philosophy, vision and values, leaders define the strategy, structure, and systems of local self-government that will contribute to the sustainable development and improvement of the quality of people's life. Good management of natural resources and achievement of sustainable development is the result of an efficient leadership of local self-government. 


\section{Conflict of interests}

The authors declare no conflict of interest.

\section{References}

1. Aristigueta, M.P., \& Zarook, F.N. (2011). Managing for results in six states. Public Performance \& Management Review, 35(1), 177-201.

2. Borins, S. (2000). Loose cannons and rule breakers? Some evidence about innovative public managers. Public Administration Review, 60(6), 498-507.

3. De Waal, A.A. (2010). Achieving high performance in the public sector. Public Performance \& Management Review, 34(1), 81-103.

4. Đukić, S, Glavaš-Trbić D, Banjac N. (2017) Management problems of rural development in Fruška Gora, Economics of Agriculture vol.64, iss.1, pp. 27-40, Original scientific paper [in Serbian: Problemi upravljanja ruralnim razvojem u području Fruške gore, Ekonomika poljoprivrede, vol.64, iss.1, pp. 27-40]

5. Grinberg, J. (2001) Practicing popular social justice: Authentic participation and democratic critical leadership in the case of a community center in Caracas, Venezuela. Paper presented at the Annual Meeting of the American Educational Research Association, Seattle, WA

6. http://www.rasr.si/si/files/default/Isto\%C4\%8Dna\%20Srbija.pdf/ (18 May 2019)

7. http://www.stat.gov.rs/sr-latn/oblasti/stanovnistvo (03 June 2019)

8. http://www.sustainabilityleadershipinstitute.org/atomic.php, (03 June 2019)

9. Jepson, E.J. (2004). the adoption of sustainable development policies and techniques in u.S. cities: how wide, how deep, and what role for planners? Journal of Planning Education and Research, 23(2), 229-241.

10. Jovanović V. (2016) Organizational learning as a factor of the sustainability management companies, Faculty of management Zaječar, $\mathrm{PhD}$ thesis [in Serbian: Organizaciono učenje kao faktor održivog upravljanja privrednim društvima, Fakultet za menadžment Zaječar, Doktorska disertacija]

11. Jovanović, V., Paunković, D., \& Stevanović, M. (2017). Organizational learning for sustainable development: Correlation with the national culture dimensions framework. Megatrend revija, 14(3), 1-19.

12. Kaiser, R.b.; Hogan, R.; \& Craig, S.b. (2008). Leadership and the fate of organizations.

13. Krause, R.M. (2010). Policy innovation, intergovernmental relations, and the adoption of climate protection initiatives by u.S. cities. Journal of Urban Affairs, 33(1), 45-60.

14. Peters, T., 1989. Thriving on Chaos: Handbook for a Management Revolution. Harper Business. 
15. Petrov V., Trivić N., Ćelić Đ. (2018) Assessing sustainability of the Southeast European economies, Ekonomika poljoprivrede, vol. 65, iss.2, pp. 519-529

16. Paunković J., Jovanović, V., Žikić S (2018) Relationship between organizational structure and culture - case studies of mining companies in Serbia, Mining and Metallurgy Engineering Bor, iss.1-2, 2018, ISSN 2334-8836 (printed edition), ISSN 2406-1395 (Online)

17. Pressman, J.1., \& Wildavsky, A. (1973). Implementation: How great expectations in Washington are dashed in Oakland; or, Why it's amazing that federal programs work at all. Berkeley: University of California Press.

18. Robbins, S. (2003), Organizational Behavior, Pearson Education, Upper Saddle River, NJ

19. Robbins, Stephen P. and Timothy A. Judge, 2013. Organizational Behavior, 14th Edition, New York: Prentice Hall.

20. Saha, D., \& Paterson, R.G. (2008). Local government efforts to promote the "three E's" of sustainable development. Journal of Planning Education \& Research, 28, 21-37. Salamon, 1.M. (2002). The tools of government: A guide to the new governance. New York: Oxford University Press.

21. Shafique, I., \& Kalyar, M. (2018). Linking transformational leadership, absorptive capacity, and corporate entrepreneurship. Administrative Sciences, 8(2), 9.

22. Sharp, E.b.; Daley, D.M.; \& Lynch, M.S. (2011). Understanding local adoption and implementation of climate change mitigation policy. Urban Affairs Review, 47(3), 433-457.

23. Stevanović M. (2017) Sustainable development as a strategic component of managing organizations in the energy sector, $\mathrm{PhD}$ thesis, Faculty of management Zaječar [in Serbian: Održivi razvoj kao strateška komponenta upravljanja organizacijama u oblasti elektroenergetskog sektora, doktorska disertacija, Fakultet za menadžment Zaječar]

24. Stoner, J. A. F.; Freeman, R. E.; Gilbert Jr., D. R. (1995). Management (6th ed.). Englewood Cliffs, NJ: Prentice-Hall.

25. Sustainability Leadership Institute, 2011. Website www. sustainabilityleadershipinstitute.org [Accessed 15 July 2011]

26. Trottier, T; Van Wart, M.; and Wang, X. (2008). Examining the nature and significance of leadership in government organizations. Public Administration Review, 68(2), 319-333.

27. Van Wart, M. (2011). Dynamics of leadership (2nd ed.). Armonk, NY: M.E. Sharpe.

28. Vilke, R., Gedminaite-Raudone, Z, Cvijanović, D. (2019) Future drivers of rural prosperity in knowledge age: Lithuanian case, Economics of Agriculture, vol. 66, iss. $1,143-157$

29. Visser V. (2011) Sustainability Leadership: Linking Theory and Practice, University of Cambridge, Institute for Sustainability Leadership 
30. Wang X., Van Wart M., Lebredo N. (2014) Sustainability Leadership in a Local Government Context - The Administrator's Role in the Process, Public Performance \& Management Review, Vol. 37, iss. 3, March 2014, pp. 362-386.

31. Wang, X., Hawkins, C. V., Lebredo, N., \& Berman, E. M. (2012). Capacity to sustain sustainability: A study of US cities. Public Administration Review, 72(6), 841-853.

32. Zhao, J., Ma, C., Zhao, X., \& Wang, X. (2018). Spatio-temporal dynamic analysis of sustainable development in China based on the footprint family. International journal of environmental research and public health, 15(2), 246. 